\title{
Ignatian Pedagogy as a Frame for Universal Design in College: Meeting Learning Needs of Generation Z
}

\author{
J. Mark Pousson and Karen A. Myers *ii \\ Department of Higher Education Administration, School of Education, Saint Louis University, \\ 3500 Lindell Blvd., St. Louis, MO 63103, USA; mark.pousson@slu.edu \\ * Correspondence: karen.myers@slu.edu
}

Received: 31 August 2018; Accepted: 1 November 2018; Published: 5 November 2018

check for updates

\begin{abstract}
In viewing the principles of Universal Instructional Design (UID), both inside and outside the classroom, a direct connection may be made to the principles of Ignatian pedagogy-a 500-year old tradition of education-in meeting the learning needs of today's college students, Generation Z. The Ignatian pedagogy as a frame for universal instructiosnal design principles can guide instructors to understand how college students can learn best and facilitate that knowledge acquisition to serve the common good. This article addresses Generation Z's experience with digital technology and illustrates how the Ignatian pedagogical model tenets (i.e., context, experience, reflection, action, and evaluation) connect with UID practices in a higher education curriculum. Examples of UID, as it applies to each tenet and to web access, are included.
\end{abstract}

Keywords: universal design; universal instructional design; Jesuit tradition; Ignatian pedagogy; Generation Z

\section{Introduction}

The basic premise of the universal instructional design is that curriculum should include alternatives to make it accessible and applicable to students with diverse backgrounds, learning styles, abilities, and disabilities [1]. Applied to higher education, the primary goal of Universal Design is to create inclusive, flexible, customizable products, courses, technologies, programs, activities, and environments. Although various titles and acronyms are employed to describe this universal design, as it relates to learning, such as Universal Design for Learning (UDL), Universal Design for Instruction (UDI), and Universal Instructional Design (UID) [2], UID is the terminology that has been used in this article. Universal Instructional Design (UID) is an educational framework, which provides learners with multiple ways of acquiring knowledge, demonstrating knowledge, and engaging in their learning. It is used as a model for equitable access; diversity, multiculture, and disability education; ally development and social justice [2-7].

Benefits of UID are ever-growing to include cost effectiveness, efficiency, enhancing engagement in learning, minimizing individualized accommodations, recognizing individual differences among learners, including differences in learning styles, and allowing multiple methods of teaching and learning both inside and outside the classroom [3,5,7]. Although challenges may arise, including advanced planning/time constraints, familiarity with local resources, administrative support, and knowledge of available technologies, the benefits of the UID tend to outweigh the costs. For example, providing all students with class notes in online accessible formats and exams with unlimited time restraints promotes an equitable learning environment respectful of the students' learning preferences. 
Influenced by Chickering and Gamson's "Seven Principles for Good Practice in Undergraduate Education", [8] and the Center for Universal Design's "Principles of Universal Design" [9], researchers at the University of Minnesota, Twin Cities created the following UID principles:

- Create a classroom climate that fosters trust and respect.

- Determine the essential components of the course.

- Provide clear expectations and feedback.

- Explore ways to incorporate natural supports for learning.

- Provide multimodal instructional methods.

- Provide a variety of ways to demonstrate knowledge.

- Use technology to enhance learning opportunities.

- Encourage faculty-student contact. [10]

In viewing these principles, a direct connection may be made to the principles of Ignatian pedagogy (i.e., context, experience, reflection, action, evaluation) demonstrating how the Jesuit tradition of education can frame UID in higher education, particularly its use of pedagogical methods and recommendations for website development. Advancement in technology has played a significant role in fostering UID and is instrumental in its global application and growth $[3,11]$. Reflecting on the make-up and learning styles of current college students and their understanding and use of technology, provides a framework for the application of UID both inside and outside the classroom. The focus of this article will be how the Ignatian pedagogical model of Catholic, Jesuit universities can frame universal instructional design in meeting the learning needs of Generation Z. To this end, the article will highlight the following areas: Generation $\mathrm{Z}$ and its experience with technology; the five components of Ignatian pedagogy and each component's UID connection; and Ignatian pedagogy via web access, incorporating examples of UID practices in web accessibility.

\section{Current College Students, Learning, and Technology}

The current student cohort, Generation Z, born after 1995, exhibit unique characteristics that are different from their predecessor, the Millennials. This generation of students has been shaped by technology more so than the other generations preceding them. It is through technology they have learned about the major social ills of the $21^{\text {st }}$ century, such as matters of violence, unpredictable economy, and various social issues. They grew up in a post $9 / 11$ environment with palatable tension between ethnic groups and witnessed the effect of the unstable economy on their parents and their immediate families. The Internet and social media broadcast public shootings and unresolved violence and terrorism, on the national and the international scenes. Regardless of fear and worry, instilled by the world presented by the Internet, Generation $Z$ students believe they can change the world [12].

The developmental needs of Generation $Z$ college students are acutely evident, based on their acquisition methods of information and career aspirations. While college students have had access to digital technologies, their access varies; thus it is difficult to generalize that all college students have equal access to, and are immersed, in digital technologies [13]. In the same vein, these digital natives use a variety of digital technology to be socially connected with others, but its use in academic settings is marginal [13,14]. It has been found that students' critical thinking skills are underdeveloped when accessing and evaluating information received from the Internet, thus, suggesting their digital technology skills are basic at the most [15]. Despite the lack of congruity about how this generation of college students' learning preferences are influenced by their use of digital technology, their contributions to the make-up of the college community is evident.

$\mathrm{A}$ unique characteristic of Generation $\mathrm{Z}$ is their penchant for intrapersonal learning. They prefer to learn independently and at their own pace. Once they have learned the specific course content, they then enjoy working in group settings where they can engage in classroom discussions to apply the content they have learned. While they want a voice in setting their own learning pace, they see the benefits from working with others. Logic-based approaches and experimental learning are their 
preferred forms of learning since these approaches allow for information to be organized into solutions and discovering which ones are appropriate for real-life situations $[12,16]$. The juxtaposition of intrapersonal and interpersonal learning contributes to their desire to be educated in relevant and applicable knowledge appropriate for the workforce, due to the ramifications of the economic and societal issues facing them and their families of origin [12]. Their learning preference is one where they can learn applicable knowledge and skills for the workforce. In many ways, Generation Z presents colleges and universities with a challenge to rethink its curriculum from being teacher-centered to learner-centered [16].

Building upon the learning preferences of Generation Z, university faculty members have an opportunity to use the talents and interests of the contemporary learner in assisting them in their pursuit of knowledge. Faculty may dictate what the learner needs to learn, but not how they learn. Generation $Z$ seeks engaging instructors who do not rely on a lecture format. Since they prefer a hands-on approach to their learning, Generation $Z$ prefers to take an active role in how they learn rather than a passive stance experienced when listening to an instructor lecture [12].

While college faculty may not have learned pedagogy in their terminal degree programs, the Ignatian pedagogy, as a frame for universal instructional design principles, can guide them in their task to learn how college students learn best and facilitate their knowledge acquisition to serve the common good of others. Since Generation $\mathrm{Z}$ has been raised with a technological advantage over and above previous generations, regarding knowledge of global and national issues, these students could benefit from a curriculum tailored to their strengths, such as persistence, realists, and desiring to make positive social changes in the world $[12,17,18]$. The following section offers applications of the UID principles via the tenets of Ignatian pedagogy.

\section{Jesuit Tradition of Education and Ignatian Pedagogy}

Ignatius Loyola founded the Jesuit Order in 1540 and the Order started teaching university students in 1548. The Jesuits often quote Cicero, "We are not born for ourselves alone" [19]. With Cicero in mind, Ignatian education is a collaborative process between teachers and learners where inquiry, creativity, discovery, and reflection aid in personal and professional development in the service to others [20]. Teachers and staff share in the academic, affective, and spiritual development of learners. In the Ignatian pedagogy, everyone shares and joins the learners in a process that includes context, experience, reflection, action, and evaluation [20]. Each element of the five-fold model of Ignatian pedagogy builds off each other; these have been described below.

\subsection{Context}

Ignatian pedagogy begins with the human experience. Thus, it is critical for faculty and student affairs professionals to understand the students' context within which learning occurs. At the microsystem level, context refers to the learner's background, such as family, society, economics, culture, faith tradition, and other variables that affect the learning process. The contextual elements at the mesosystem level include the institutional environment of the college or university. Here, it is important to learn how these elements contribute to the climate for learning. Likewise, it is important to learn how the students' context at the macrosystem level, such as socioeconomic, political, and cultural elements, affect their growth as a person. Lastly, it behooves instructors and student affair professionals to learn what pertinent knowledge students bring with them, to the learning environment. A focus on their feelings, attitudes, and values, pertaining to their knowledge base, helps the instructor or professional in having a holistic perspective of the students [21].

The following examples are ways in which the Universal Instructional Design [UID] can be incorporated in the Ignatian pedagogical component of context. Getting to know students' backgrounds and learning styles will help instructors create welcoming and respectful learning environments for students. This may be accomplished by sending a welcome email to students, prior to the beginning of the class; creating introductory exercises that are personable, friendly, and encourage humor; 
encouraging students to share photos of themselves and their families, pets, vacations, favorite places, favorite food, etc.; learning students names and using their names in communication; collecting information about one's students via a student information sheet or interest inventory; including a syllabus statement that fosters an inclusive learning environment; being open to meeting with students face-to-face or online (e.g., "virtual office hours" via Google Chat, Fuze Meeting, Skype, etc.), and letting students know from the outset the environment is inclusive and their voices will be heard. Instructors may determine the learning styles of their students by asking students to complete the VARK (Visual, Aural, Read/Write, and Kinesthetic) assessment, a guide to learning styles, by Neil Fleming [22] and share their results with the class, thus informing others of their preferred ways of learning. Complimenting student participation and effort may foster a welcoming and respectful environment.

The authors of this scholarly piece teach graduate students in a higher education academic program. Throughout the semester, the authors seek feedback from the graduate students on their experience with the course and what could make their learning better, as the semester progresses. This information is evaluated against the course objectives. If appropriate, adjustments are made, thus, creating a context where students' learning goals can be better met.

All aspects of the Ignatian pedagogy lead to "its ultimate goal ... to develop men and women of competence, conscience and compassion" [21] (p. 158). The challenge of the Ignatian pedagogy, for the educators, is to infuse in the curriculum experiences an active reflection on the systemic dimensions of the experience. To gain further understanding of the importance of experience and reflection, faculty can learn from the $20^{\text {th }}$ century educator, John Dewey.

John Dewey had a keen understanding of the nature of knowledge and society. His pragmatic and experiential approach to knowledge was central to his educational philosophy. He argued against the early $20^{\text {th }}$ century view on the acquisition of knowledge. Knowledge was perceived to be fundamentally empirical and theoretical, thus acquisition was passive. He challenged the current perspectives by arguing that knowledge is about responding to one's situation in the world. It is then a way to maneuver, in the world. He acknowledged a natural tension in obtaining knowledge. If one is not sensing a challenge in learning, then reflection, analysis, and defining knowledge cannot take place. It is through experience that valid knowledge is acquired, helping the learner to resolve problems of doubt [23].

This active way of learning has two key benefits. The first is that kinesthetic learning allows learners to understand concepts of science and the humanities by applying them to concrete situations. Memorization and regurgitation of facts can be helpful but applying them provides a breadth and depth that aids in long-term memory formation. Dewey suggests that when students are involved in real life contexts, the material is interesting [23].

Dewey argued for an "education of, by and for experience" [23] (p. 29). An education by experience allows learners to learn through experiences inside and outside the classroom. An education of experience challenges learners to make sense of knowledge by using the intellectual gain in preparing learners to deal with future situations [23]. While not all experiences are equally educative, experiences allow the learner an open mind and foster an intelligent response to realistic situations. The faculty member's task is to create experiences with the goal of developing students to be global citizens who use intelligent resourcefulness in responding to the societal ills [23].

\subsection{Experience}

Capitalizing on Generation Z's interests, strengths, and natural inclination to gather information from the Internet, allows instructors to not just be agents of knowledge but facilitate a process for making sense of the overabundance of information [12]. The task of the instructor is to engage students by determining essential program components; establishing clear expectations and feedback; developing natural supports for learning through technology and other modes; and using multiple teaching methods that consider diverse learning styles, abilities, ways of knowing, and previous 
experience and background knowledge. Experiences are meant to challenge and confront students' knowledge, at that point in time. These can perturb the students' learning cycle and trigger new growth. With context in mind, the teacher can create experiences to engage students, holistically. Here, experiences move the student beyond their cognitions to include their heart and will in the learning experience. Without the inclusion of the imagination and emotions, within the cognitive dimension, the student would not be moved to action [21].

Experiences can be direct or vicarious. Direct experiences are interpersonal in nature where discussions, service projects, or participation in sports lend themselves to learning new knowledge [20]. Instructors can create experiences for Generation $Z$ which align with their interest to change the world through invention. Generation $Z$ prefers community engagement opportunities where they can make a lasting impact on the underlying social ills. They do not think in terms of short-term gains but rather in long-term gains. Thus, this generation thinks more as social entrepreneurs [12]. As social change entrepreneurs, this generation seems more interested in working for themselves after college, thus, cultivating the current gig economy where workers engage in freelance work. Internships while in college are especially important to their overall development [12].

Vicarious experiences challenge the student to use their imagination and senses to enter more fully into the topic at hand. Use of reading materials, simulations, role playing, and videos are good examples. By offering a broad array of experiences, appropriate to the course content, instructors and professionals can expect learners to attend, apply, analyze, synthesize, and evaluate the variables that confront the human condition [21].

The following examples are additional ways Universal Instructional Design (UID) can be incorporated in the Ignatian pedagogical component of experience. Instructors may consider utilizing multi-modal teaching techniques including, lecture, large group discussion, small group discussion, think-pair-share, role playing, case studies, games, exercises, guest speakers, panels, movies, videos, podcasts, vodcasts, and project- or problem-based learning. Ensuring all field trips, labs, and educational opportunities outside of the classroom are accessible to all students and establishing learning communities and/or "study buddies", in the course, to provide students with classmate resources and peer-to-peer learning opportunities will enhance the universal learning.

\subsection{Reflection}

The subjective nature of knowledge acquisition includes making judgments about new information. One developmental area affected by the consequence of Generation Z college students' involvement in technology, is reflection. In a world where continued stimulation prevails, due to the variety of technological platforms, there tends to be less time for reflection, where learning takes place from making meaning from the diverse experiences encountered daily [24].

College faculty have an opportunity to integrate reflective activities in their courses to strengthen the learning effect of the course content. Purposeful, critical reflection intentionally engages students to consider their experiences, considering specific learning objectives [25], [26]. Reflection, the third Ignatian pedagogical component, is used by the faculty to understand what meanings students derive from the course content. Key to the learning process, teachers develop questions and guide discussion, writing assignments and other activities that tie the learners' experiences to the course content. Students are asked to answer the following questions: What course components/experiences stand out; What is the significance of the content/experience considering your learning objectives? What will you do with the new knowledge? In doing so, this provides a depth and breadth of the meaning to their learning. Reflection allows students to discern and clarify the reasons for the judgments. Instructors and professionals can develop reflective activities for students to utilize in naming the meanings attached to what is being learned and uncover its link to other knowledge, their developing a sense of self, and human endeavors, all the while appreciating the evolutionary dimension of the search for truth. Reflection aids in the conscience formation of students, thus moving them to act [21]. 
Capitalizing on Generation Z college students' preference for intrapersonal learning, multiple types of UID opportunities exist for students to critically reflect upon their knowledge of the course content. Instructors may accomplish this by offering students the option of papers, presentations, PowerPoint's, online presentations via narrated PowerPoints, or through Tegrity, team assignments, poster sessions, role playing, websites, games, exercises, case studies, online discussions, individual and group projects, structured journal entries and writing assignments; and multi-media products, such as drawings, collages, and photo, or video essays.

\subsection{Action}

By reflecting on their experiences, both cognitively and affectively, students are then moved to action. The term action refers to the students' internal growth which involves two steps. Considering their cognitive understanding of the experience and the resulting affect, students' growth occurs when they decide that the new knowledge will clarify their values and priorities and allow the truth to guide their continued growth. Eventually, this new, interiorized knowledge may prompt students to do something consistent with their new-found knowledge. From the reflection of their contextual experiences, students can own their own knowledge base and serve others, thus bettering the welfare of society and themselves [21].

Upon reflection of their experiences, learners determine action, the fourth Ignatian pedagogical component, by asking themselves, "Now what?" How may they use their knowledge to serve others and better the welfare of humanity? Given Generation Z's description of themselves as change agents and desire to create change but lacking the creativity to do so, faculty may need to guide Generation $\mathrm{Z}$ college students in determining their next steps, with their knowledge base [27]. Encouraging contact between/among students, instructors, and others is a universal design principle which supports action. Good practices of the Universal Instructional Design (UID) incorporated into the Ignatian pedagogical component of action may include, being available and encouraging conversation and assistance via email, chat, phone, discussion board, chatrooms, and in person; encouraging students to develop peer learning communities, study groups and collaborative efforts via Google Docs, wikis, social media, and websites; and promoting student engagement with current and potential employers through electronic portfolios such as Foliotek. Additional ideas include students creating action steps addressing problems they and their friends encounter, petitioning for improvements in community services, and immersing themselves in community programs serving the minoritized populations [27].

\subsection{Evaluation}

University faculty know and value the periodic use of measures to evaluate students' acquisition of knowledge. These evaluative measures are intentional "check -ins" which allow the teacher and students to determine where there is intellectual growth and gaps in knowledge. This information alerts the teacher to possible shifts in pedagogical methods and opportunities for individualized attention on each student. Teachers evaluate the whole person using effective means, such as assessment, writing assignments, and critical skill application [21].

A myriad of Universal Instructional Design (UID) practices align well with the fifth and final Ignatian pedagogical component of evaluation. UID examples of evaluation include providing students with completed grading rubrics, including written comments in a timely manner (i.e., preferably at least one week prior to the due date of the next assignment); discussing in class the overall strengths and weaknesses of the completed assignments; asking students to complete peer evaluations for team members; encouraging students to submit assignments at least one week prior to due date for teacher and peer review, before resubmitting revised assignment; asking students to do a one-minute paper at the end of the class to outline what they learned, indicate when they were the most/least engaged, and provide comments about the day's class; and providing students with information regarding how to access support structures, such as tutoring, writing center, and other out-of-class assistance. 
Ignatius Loyola and John Dewey believed engagement in the world complements the pursuit of empirical and theoretical knowledge. Experience becomes a portal into a dimension that the written word cannot adequately provide. The challenge is one, both, Ignatius Loyola and John Dewey faced themselves as educators, that of how to create transformative experiences. This is not unique unto educators. Students, through their use of technology, seek new knowledge to further their human and professional development. To meet Generation Z's expectations regarding technology, the next logical step in applying the Universal Instructional Design (UID) principles to the Ignatian Pedagogy is via website access. Promoting UID as a framework for such learning via technology offers learners an inclusive, welcoming environment, thus, embracing and embodying the spirit of the law.

\section{Ignatian Pedagogy via Web Access}

Despite the apparent expectations of current college students toward technology, "the digital divide" may construct barriers to impede access. Three such barriers identified by Nielson include economic (ability to access or own), usability (knowledge base and skills), and empowerment (comprehension of the benefits) [28]. To meet Generation Z's expectations regarding technology and to address the digital divide, the next logical step in applying the UID principles to Ignatian pedagogy is via website access. Building upon the teachings of Ignatius Loyola and John Dewey, educators create transformative experiences for learners through reflection and action. Promoting UID as a framework for such learning via technology offers learners an inclusive, welcoming environment, thus, embracing and embodying the spirit of the law.

As previously stated, the letter of the law in the United States regarding inclusion and discrimination of people with disabilities, continues to be questioned. In 2017, Vu and Sverdlov reported over eight hundred federal complaints about allegedly inaccessible websites being filed, with three hundred and forty-nine complaints being filed in January and February of 2018; a trend indicating the number of complaints and lawsuits will be increasing [29].

The Americans with Disabilities Act of 1990 [30] protects the rights of people with disabilities to visit, interact with, and benefit from all that the internet has to offer. Although the federal government has not provided specific guidelines for web access, courts are ruling in favor of web accessibility demonstrated in cases involving corporations such as Winn Dixie, Hobby Lobby, Five Guys Restaurant, and Blick Art Materials, among others. Per Lewin, given this litigious pattern, which includes federal lawsuits against Harvard University and MIT for not providing closed captioning for online courses and other education materials, trends indicate additional educational institutions most likely will be defendants in such cases. Therefore, making all electronic materials accessible to all users, including people with disabilities, is essential [31].

Ensuring compliance by identifying and following recommendation and the legal mandates, is one way to accomplish this. Sources for the web content standards include (1) Web Content Accessibility Guidelines [32] developed through the Web Accessibility Initiative (WAI) of the World Wide Web Consortium (W3C), a global consortium of individuals and organizations, around the world, providing a shared standard for web content accessibility. (2) Section 508 of The Rehabilitation Act Standards [33], which was updated on January 18, 2017 by the Architectural and Transportation Barriers Compliance Board with requirements for information and communication technology, covered by Section 508 of the Rehabilitation Act and Section 255 of the Communication Act [34]. Section 508 of the Rehabilitation Act is a procurement legislation that applies only to the U.S. federal agencies.

Another natural step in making a campus' electronic materials accessible to all users is through Universal Instructional Design (UID). Incorporating UID principles in technology will allow entities, including colleges and universities, to move beyond the letter of the law and live the spirit of the law, by providing inclusive welcoming environments for everyone. Aligning these web access guidelines with the UID principles will lead to the creation of welcoming, respectful online environments, thus, promoting Jesuit traditions of care (i.e., cura personalis, care for the whole person) and inclusion and potentially meeting the expectations of current college students. 
The Web Content Accessibility Guidelines Checklist includes the following recommendations: Provide text alternatives for all non-text content; provide synchronized alternatives for multimedia; make it easy to distinguish foreground information from its background; allow users to control time limits on their reading or interaction; allow users to avoid content that could cause seizures due to photosensitivity; provide mechanisms to help users find content, orient themselves within it, and navigate through it; help users avoid mistakes and make it easy to correct mistakes that do occur; make text content readable and understandable; make the placement and functionality of content predictable; support compatibility with current and future user agents (including assistive technologies); and ensure content is accessible or provide an accessible alternative. A useful resource on the WAI website is Easy Checks-A First Review of Web Accessibility [35].

\section{A UID-Friendly Website}

In the spirit of Ignatius Loyola and the Jesuit values of teaching and learning, a respectful, welcoming environment for all human beings is essential. At the 2018 World Meeting of Universities Entrusted to the Society of Jesus, Father General expressed to higher education Jesuit leaders "the importance of recognizing others as their equals in terms of dignity and rights" [36] [p. 6]. In today's world, a website can be the first impression, indicating how we recognize human dignity. It can be the window to one's philosophy, personality, and perspectives, demonstrating how we see and value others. A universally designed website considers the needs of all people, including individuals with disabilities, individuals older or younger than the average user, people for whom English is a second language, and those using outdated hardware and software [3]. Utilizing the above resources and working with web accessibility experts, such as the World Wide Web Consortium, is essential when creating UID-friendly accessible websites. Here are some examples of creating an inclusive, welcoming, website. Begin with a clear, easy-to-read format. Large sans serif font (i.e., font without tails) in a high contrast background, with plenty of "white space" (thus, few words in an uncrowded space). These key components, particularly those with a keen understanding of the screen reader software, i.e., text-to-speech programs, provide accessibility for a variety of individuals who have low vision, cognitive, and learning disabilities. Although flashy colors, moving parts, and an abundance of photos seem to be standard in websites today, these factors may result in inaccessible environments. To "read" the website, the screen reader software requires stationary text, alternate text for photos and illustrations, and descriptions of visuals [37]. Captioning, written text, and text transcripts provides access to videos and audio materials. The University of Washington DO IT website provides useful instruction and examples for designing accessible website. Resources on the DO IT website, related to website development, include AccessSTEM, AccessWEB, Faculty Room, and the Center for Universal Design in Education [38].

\section{Conclusion}

As the United States awaits new regulations about the websites of public accommodations and state and local governments, private and public colleges and universities are encouraged to move forward in ensuring equal access to its online information and curriculum. Instrumental in the education of today's college students is attention to the learning needs of Generation Z, particularly their experience with and expectations surrounding digital technology. As teachers and staff share in the development of students, they may join in the transformative learning process vis-à-vis context, experience, reflection, action, and evaluation-each component, building upon the other. With the Jesuit tradition of education and Ignatian pedagogy as a frame for universally designed learning and instruction, the 500-year old tradition of the Ignatian pedagogy lives on in college educators and their students as they develop and utilize UID-friendly curriculum, websites, programs, and services, thus, modeling a modern-day approach to inclusive education. 
Funding: This research received no external funding.

Conflicts of Interest: The authors declare no conflict of interest.

\section{References}

1. Center for Applied Special Technology. Universal Design for Learning. Available online: www.cast.org (accessed on 23 October 2018).

2. Myers, K.A.; Lindburg, J.; Nied, D. Allies for Inclusion: Students with Disabilities. In ASHE Higher Education Report; Myers, K.A., Lindburg, J.J., Nied, D.M., Eds.; Jossey-Bass: San Francisco, CA, USA, 2014.

3. Burgstahler, S. Universal Design in Higher Education: From Principles to Practice, 2nd ed.; Harvard Education Press: Cambridge, MA, USA, 2015.

4. Evans, N.; Broido, E.; Brown, K.; Wilke, A. Disability in Higher Education: A Social Justice Approach; Jossey-Bass: San Francisco, CA, USA, 2017.

5. Higbee, J.L.; Goff, E. Pedagogy and Student Services for Institutional Transformation (PASS-IT): Implementing Universal Design in Higher Education; Regents of the University of Minnesota: Minneapolis, MN, USA, 2008.

6. Higbee, J.L.; Mitchell, A. Making Good on the Promise: Student Affairs Professionals with Disabilities; University Press of America: Lanham, MD, USA, 2009.

7. Rose, D.; Meyer, A. A Practical Reader in Universal Design for Learning; Harvard Educational Press: Cambridge, MA, USA, 2006.

8. Chickering, A.; Gamson, Z.F. Seven Principles for Good Practice in Undergraduate Education. AAHE Bull. 1987, 39, 3-7.

9. The Center for Universal Design. The Principles of Universal Design, Version 2.0. [Brochure]; North Carolina State University: Raleigh, NC, USA, 1997.

10. Fox, J.; Hatfield, J.; Collings, T. Developing the Curriculum Transformation and Disability Workshop Model. In Curriculum Transformation and Disability: Implementing Universal Design in Higher Education; Higbee, J.L., Ed.; University of Minnesota: Minneapolis, MN, USA, 2003; pp. 23-40.

11. Duranczyk, I.; Myers, K.A.; Couillard, E.K.; Schoen, S.; Higbee, J.L. Enacting the Spirit of the United Nations Convention on the Rights of Persons with Disabilities: The Role of Postsecondary Faculty in Ensuring Access. J. Divers. Manag. 2013, 8, 63-72. [CrossRef]

12. Seemiller, C.; Grace, M. Generation Z Goes to College; Jossey-Bass: New York, NY, USA, 2016.

13. Bullen, M.; Morgan, T.; Qayyum, A. Digital Learners in Higher Education: Generation is Not the Issue. Can. J. Learn. Technol. 2011, 37, 1-24. [CrossRef]

14. Margayan, A.; Littlejohn, A.; Vojt, G. Are Digital Natives a Myth or Reality? Students Use of Technologies for Teaching and Learning. Comput. Educ. 2011, 56, 429-440. [CrossRef]

15. Lorenzo, G.; Dziuban, C. Ensuring the Net Generation is Net Savvy. Educause Learn. Initiative 2006, 2, 1-19.

16. St. Martin, G. Generation Z and the Future of Higher Education. 2014. Available online: https:/ / news.northeastern.edu/2014/11/19/generation-z-and-the-future-of-higher-education/ (accessed on 23 October 2018).

17. Schwieger, D.; Ladwig, C. Reaching and Retaining the Next Generation: Adapting to the Expectations of Gen Z in the Classroom. Inf. Syst. Educ. J. 2018, 16, 45-54.

18. Merriman, M. What If the Next Big Disruptor isn't a What but a Who? Gen Z is Connected, Informed and Ready for Business. 2015. Available online: https://www.ey.com/Publication/vwLUAssets/EY-rise-ofgen-znew-challenge-for-retailers /\%24FILE/EY-rise-of-gen-znew-challenge-for-retailers.pdf (accessed on 23 October 2018).

19. OMalley, J. From the 1599 Ration Studiorum to the Present: A Humanistic Tradition? In The Jesuit Ratio Studiorum: 400th Anniversary Perspectives; Duminiuco, V., Ed.; Fordham University Press: New York, NY, USA, 2000; pp. 127-144.

20. Duminuco, V. A New Ratio for a New Millennium? In The Jesuit Ratio Studiorum: 400th Anniversary Perspectives; Duminiuco, V., Ed.; Fordham University Press: New York, NY, USA, 2000; pp. 145-161.

21. Duminuco, V. Appendix B Ignatian Pedagogy: A Practical Approach, 1993. In The Jesuit Ratio Studiorum: 400th Anniversary Perspectives; Duminiuco, V., Ed.; Fordham University Press: New York, NY, USA, 2000; pp. 251-262.

22. VARK. A Guide to Learning Styles. Available online: www.vark-learn.com (accessed on 23 October 2018). 
23. Rocheleau, J. Theoretical Roots of Service-Learning: Progressive Education and the Development of Citizenship. In Service-Learning: History, Theory, and Issues; Speck, B., Hoppe, S., Eds.; Praeger Publishers: Westport, CT, USA, 2004; pp. 3-22.

24. Prensky, M. Digital Natives, Digital Immigrants Part 1. On Horiz. 2001, 9, 1-6. [CrossRef]

25. Eyler, J. Creating Your Reflection Map. In Service-Learning: Practical Advice and Models; Canada, M., Ed.; Jossey-Bass: San Francisco, CA, USA, 2001; pp. 35-43.

26. King, P. Learning to Make Reflective Judgments. New Dir. Teaching Learning 2000, 82, 15-26. [CrossRef]

27. Mohr, K.; Mohr, E. Understanding Generation Z Students to Promote a Contemporary Learning Environment. J. Empowering Teach. Excell. 2017, 1, 84-94.

28. Nielsen, J. Digital Divide: The 3 Stages. 2006. Available online: https://www.nngroup.com/articles/digitaldivide-the-three-stages / (accessed on 23 October 2018).

29. Vu, M.; Sverdlov, S. Member of Congress Urge DOJ to Declare that Private Website Accessibility Lawsuits Violate due Process. 2018. Available online: https://www.adatitleiii.com/lawsuits-investigationssettlements/?utm_medium=email\&utm_source=govdelivery (accessed on 23 October 2018).

30. Americans with Disabilities Act of 1990. Available online: https://www.ada.gov/pubs/ada.htm (accessed on 23 October 2018).

31. Lewin, T. Harvard and M.I.T. are Sued over Lack of Closed Captions. 2015. Available online: https: / www.nytimes.com/2015/02/13/education/harvard-and-mit-sued-over-failing-to-captiononline-courses.html?utm_medium=email\&utm_source=govdelivery (accessed on 23 October 2018).

32. Web Content Accessbility Guidelines. 2008. Available online: https://www.w3.org/TR/WCAG20/ (accessed on 23 October 2018).

33. The Rehabilitation Act of 1973. 2015. Available online: https://www2.ed.gov/policy/speced/reg/narrative. html (accessed on 23 October 2018).

34. United States Access Board. 2018. Available online: https://www.access-board.gov/ (accessed on 23 October 2018).

35. Easy Checks-A First Review of Web Accessibility. 2017. Available online: https://www.w3.org/WAI/testevaluate/preliminary/ (accessed on 23 October 2018).

36. Sosa, A. The University as a Source of a Reconciled Life. In Proceedings of the World Meeting of Universities Entrusted to the Society of Jesus, University of Deusto, Bilbao, Spain, 8-12 July 2018.

37. W3C Working Draft: Appendix B Checklist (Non-Normative). N.D. Available online: https://www.w3.org/ TR/2006/WD-WCAG20-20060427/appendixB.html (accessed on 23 October 2018).

38. DO IT. Available online: www.uw.edu/doit/ (accessed on 23 October 2018). 